Comparative Philosophy Volume 10, No. 1 (2019): 192-207

Open Access / ISSN 2151-6014 / www.comparativephilosophy.org

https://doi.org/10.31979/2151-6014(2019).100113

CONSTRUCTIVE-ENGAGEMENT DIALOGUE (2.1)

\title{
ON MEXICAN PHILOSOPHY, FOR EXAMPLE
}

\section{CARLOS PEREDA}

\begin{abstract}
In the first part of my work I consider the false opposition between abstract universalism and cultural particularisms. I propose to dissolve it by means of a nomadic thought and take as an example of such thinking the work of Luis Villoro. The second part discusses the disagreement between Manuel Vargas and Robert Sánchez on philosophy as a cultural resource. The third part explores the genuine opposition between arrogant reason and porous reason.
\end{abstract}

Keywords: abstract universalism, arrogant reason, cultural particularism, Luis Villoro, Manuel Vargas, nomadic thought, porous reason, Robert Sánchez

Discussions about Latin American philosophy in general, but in particular discussions about any of the philosophies of the region-Mexican philosophy, for example-tend to get entangled between two false oppositions, and the first one is as characteristic and popular as it is destructive. I will begin by trying to dissolve both of them, in order to introduce towards the end of this reflection a genuine opposition that is, I believe, of greater value.

1.

In order to present the first false opposition, which I consider as important as dangerous, I appeal to the strategy of detours. As a starting point, I'd like to answer the question: "why study Mexican philosophy?" Not infrequently, it is useful to place a question in a context, among other reasons, to determine it with some precision: in order to discover what is of interest when formulating such a question. For this reason, on this occasion I formulate the above question as follows: "Why should it matter to study Latin American philosophy and, specifically, Mexican philosophy, for example, in the United States?" The short answer is: to study Mexican philosophy-

PEREDA, CARLOS: Professor of Philosophy, Instituto de Investigaciones Filosóficas, Universidad Nacional Autónoma de México, Mexico. Email: jcarlos@filosoficas.unam.mx 
or, if you prefer, more comprehensively, Latin American philosophy - is a way to expand the tradition and, thus, to enrich it: with new voices and problems, perhaps even with other theories, methodologies, and arguments. When this short answer is given, doubts immediately arise: why should these voices, problems, and arguments be considered? This question leads me to offer a halfway response. Why halfway? As it often happens with some problems usually described as philosophical-the reference of language and rigid designators, practical and epistemic virtues and vices, freedom...- any answers proposed to these problems can in turn become starting points for other discussions that need long, very long answers. As we have to start somewhere, for the time being I will concentrate on producing a halfway response to the question that concerns us.

Regarding the short answer, it may be doubted why it should be interesting, for the analytical or the "continental" philosopher, or any other philosopher practicing in a philosophy department in the United States, to introduce in its canon or, if it is preferred, in its tradition, voices, problems, methodologies of Mexican philosophy. Predictably, answering this question depends on what is meant by Mexican philosophy. In Orosco 2016, José-Antonio Orosco ${ }^{1}$ presents a map of various ways of understanding - and, perhaps, also of misunderstanding - that philosophy. In what follows I shall reorganize that map a little.

The first way to understand it is as an abstract universalism. According to this position, there is nothing distinctive that should be referenced with expressions such as "Mexican philosophy" or "Latin American philosophy". Philosophy is a field of research such as mathematics or natural science. The truths of philosophy are only universal.

A second way is cultural particularism. Under this denomination I subsume what Orosco calls "culturalism", i.e. an understanding of philosophy as articulating a conception of the world and its culture, or some of its fragments, just the way Samuel Ramos, Leopoldo Zea or Jorge Portilla ${ }^{2}$ are assumed to have done about Mexican philosophy. I also include as a variant of this position Jorge Gracia's proposal to understand Latin American philosophy as "ethnic philosophy". For the philosophy of an ethnos - or, what is perhaps something similar, of a tradition, Gracia historicizes the Wittgensteinian metaphor of the family: an "ethnos" (or tradition?) is an extended human group that has unity or, at least, "family resemblances", given by certain historical contingencies, without implying that all the members of the group share the same properties. ${ }^{3}$

\footnotetext{
${ }^{1}$ The title of Orosco 2016 ("The Philosophical Gift of Brown Folks: Mexican American Philosophy in the United States") is a suggestive - and inspiring - variation of the book title of W.E.B. Du Bois, The Gift of Black Folks of 1924. In that book, Du Bois set out to exalt the contributions of the AfricanAmerican community to the cultural, political and economic life of the United States.

2 Ramos 1972; Zea 2004; Sánchez 2012.

3 As an introduction to the ideas of Gracia the reader may want to turn to, among other works, his Gracia 2010. Jaksic 2015 explores further and discusses these aspects in Gracia's philosophical work. I think it's fair to bring up here a remark from a review of this volume. Rivera Berruz 2016 rightly points out that: "There is no doubt that Gracia's contributions to Philosophy have been major and influential, and this book is a true testament to that fact" (28).
} 
Orosco also indicates another way of understanding Latin American philosophy that he calls "criticalism". As an example of "criticalism" Orosco recalls statements by Augusto Salazar Bondy, who points out that, since Latin America has lived under a "culture of domination", it has not had the possibility of developing an authentic philosophy; but it could do so, given different economic and political circumstances. 4 I do not consider that this is a specific way of doing Latin American philosophy - or, for example, Mexican philosophy. Critical thinking is one of the many constitutive duties of any philosophy insofar as it has been, and is, and I suppose it will continue to be, a philosophy - that is, if it does not want to betray itself. ${ }^{5}$

Consequently, two positions remain on the map that corner us into a discouraging alternative. It is the first false opposition that I am interested in dissolving. For if an abstract universalism is accepted in the existing departments of philosophy, it will surely be pointed out that the canon is already overcrowded. If, by chance, an unexpected figure or unexpected problem appears in Mexican philosophy that until now nobody had taken into account, it will be considered and introduced in the discussion; however, to give it such a consideration it is not necessary to prescribe students a course on "Latin American philosophy" or "Mexican philosophy". This is an elegant response, but it is deeply arrogant to those who have an interest in teaching (or taking) such courses: it's a way to say "Do not bother". If, on the other hand, a cultural particularism is accepted, the reaction will be equivalent. It will be observed that some neopositivists already stated that conceptions of the world are one thing and philosophy is quite another. Perhaps history, anthropology, sociology or literary theory may have an interest and instruments for studying conceptions of the world, but whoever insists on studying them in philosophy will be reminded: "Do not bother". What can we say?

Here is a conjecture: perhaps we can understand this map about Latin American, or Mexican, philosophy from two perspectives. The first perspective is to understand it from a static epistemology. Therefore, with the positions of abstract universalism and cultural particularisms, we operate with static concepts that lead to an opposition that is no less popular than it is false. This condemns us to choose: either you work with abstractions and general problems, or you abandon philosophy and attend more or less concrete problems about "conceptions of the world", or about the specific

\footnotetext{
${ }^{4}$ Salazar Bondy 2004. The well-known attacks of José Mariátegui can be located, among other critics, in an analogous direction to that of Salazar Bondy: "All the thinkers of our America have been educated in European schools. The spirit of the race is not felt in their work. The continent's intellectual production lacks its own characteristics. It does not have an original profile", in Mariátegui 1996, 118. I take this opportunity to indicate that, for sure, I expressed myself poorly but, against Orosco, I do not understand my Pereda 2006 as defending an abstract universalism; in that paper I expressed myself as one more critical participant of Latin American philosophy concerned about some of its colonial vices. Therefore I am not completely far from the criticisms of Salazar Bondy or Mariátegui. It is a critical work within the framework of what I later identify as the strategy of the passages in the perspective of an epistemic nomadism. In any case, we must not forget the controversial context - in the interior of a tradition — in which criticisms such as these are introduced.

${ }^{5}$ Salazar Bondy's criticisms or other analogous criticisms can be made both as part of an abstract universalism and as a culturalist particularism, or from other positions.
} 
circumstances of certain social groups, or even of the experience of individuals. However, in the latter case it will be concluded - again, not without arrogance - that these worldviews are not the subject of philosophy.

However, it is also possible to understand that map according to a model that has more effects than is perhaps assumed: from the perspective of a nomadic epistemology. ${ }^{6}$ In this second perspective, the positions of abstract universalism and of cultural particularisms, and even of personal singularisms - those that concern the experiences and problems of a social group and even of an individual-will no longer form an opposition. On the contrary, these positions will become the extremes of a continuum of nomadic thought: frequent comings and goings of knowledge and inquiry; on the one hand between what happens in one place and what happens in another, on the other hand between the abstract and the concrete. What do I mean with that continuum?

For example, in this way, more or less particular difficulties and problems, or apparently particular or singular difficulties and problems, arising from concrete experiences with respect to body, gender, race, language or place of origin, can often also become starting points for the formulation of problems, or challenges of customs rooted in other traditions. Therefore, one can interrogate not only, predictably, an ethical or political theory, but also an epistemology and, from this starting point, a metaphysics about the place of body, gender, race, language or place of origin. Moreover, it may be desirable, at the same time, to generalize and refine the catalog of questions and examine which problems are taken into account and privileged, or left aside, in the various theories. Are epistemic problems the colonial vices and the resistances to such vices? ? $^{7}$ Should territory and its good or bad organization, as well as the persistent concerns of human animals such as body, sexuality, desires, beliefs, emotions, violence and peace, also be concerns of metaphysics? Or is it better to think "being" or "what there is" or, if you prefer, "reality" — breathtaking words! — without the phenomenon of life; and therefore, without animals; and therefore, without the human animals that are born in certain places under certain conditions, and sooner or later die. One needs to be careful, however, with what is determined as valid problems: because what is excluded throws lights and shadows on what is included.

In turn, a nomadic thought also implies taking into account universal lessons that must operate as restrictions of particular or singular customs, perhaps even to reject them. In this way we must defend, among others, so-called "human rights". For example, in Latin America this is about resisting the constant violations of the rights

\footnotetext{
${ }^{6}$ This epistemic nomadism tries to echo in theory a vital nomadism that occurs in practice both socially - large voluntary and involuntary migrations - and personally. Such nomadisms, in various formssome more terribly painful than others - are common in the experience of a large part of the population of Latin America, including many philosophers. In Reed-Sandoval 2016, Amy Reed-Sandoval discusses several distinctions regarding these social nomadisms 'displaced', immigrants, exiles, refugees...). For her discussion, Reed-Sandoval takes as a starting place my book Pereda 2018.

${ }^{7}$ For example, José Medina deals with unusual problems in the analytical epistemological tradition. In Medina 2012 he deals with problems that concern both the production of knowledge and ignorance. Among these problems is the epistemic exclusion and the silencing of racism, sexism and homophobia, as well as the marginalization to which those exclusions condemn people.
} 
of women, of indigenous populations, of destitute people, or of what some consider to be "divergent sexualities", against abuses that disguise themselves as "protective attitudes" or, perhaps with more hypocrisy, as "cultural traditions." It is also about investigating how a condition as universal as the condition of truth places severe restrictions on the most diverse beliefs whether explicit or implicit in practices (and, for example, allows to distinguish "real" news from "fake news").

Thus, there are two resources of great utility for a nomadic epistemology. These are strategies that are often intertwined; however, it is analytically convenient to distinguish them. The horizontal nomadism or strategy of detours allows us to attend to ramifications which are sometimes outlandish in appearance. Therefore, with this strategy, more or less collateral paths are taken into account not only to illuminate experiences and actions on the main roads, but also to broaden the debates: to enrich them with problems, descriptions, and histories that sometimes burst suddenly, unexpectedly. (For example, when discussing the moral, legal and political problems of violence, it is convenient to discuss the political presuppositions of violence, or, in an epistemology of belief, not only virtuous but also vicious uses should be considered.)

In its turn, vertical nomadism or strategy of passages serves to change the level of abstraction. Moving from more abstract levels to more concrete levels of inquiry, this procedure enables reciprocal illuminations. (For example, it may help us to address in what ways social corruption and violence configure phenomena in Mexico, so that, although local, give more material to think about repercussions that are not usually suspected. Or, when a nomadic epistemology is adopted, perhaps we may worry how biases and prejudices specifically distort beliefs, for example, in Mexico or in certain social groups in Mexico.)

In nineteenth-century Mexico, from the more or less tenuous liberalism to the radical liberalism of Ignacio Ramírez $(1818-1879)^{8}$ and his intense concern for Indians, women and "day laborers" (as Ramírez called the workers), several examples of this nomadic thought can be found. In the case of Ramírez, he elaborated his vertical nomadism by articulating the more concrete naturalistic interests that he had taken from the European Enlightenment. However, I will only take a moment to review - really quickly-how the nomadic epistemology of one of the leading Mexican philosophers of the second half of the 20th century, Luis Villoro (19222014), ${ }^{9}$ dissolves the false opposition that occupies us between abstract universalism and cultural particularism.

\footnotetext{
${ }^{8}$ Ramírez (1984-1989). It is worth emphasizing here Maciel 1984 and Monsiváis 1985. As an introduction to this era, Reyes Heroles 1957 is still a valuable source.

${ }^{9}$ In this brief rereading of Villoro, I return to ideas already expressed in several of my previous works, as in in Pereda 2017. On the other hand, in Pereda 1987 I discuss in some detail his Villoro 1998a. In another book of mine, Pereda 2013, I include four works on Villoro: "On Knowledge and Servitude in Luis Villoro" ("Del saber y de la servidumbre en Luis Villoro"), "Answers and Questions to Villoro" ("Respuestas y preguntas a Villoro"), "Villoro and Wisdom" ("Villoro y la sabiduría") and "Villoro, Muguerza, and the Fight Against Arrogant Reason" ("Villoro, Muguerza y el combate a la razón arrogante").
} 
Whoever skims through the numerous writings of Villoro will immediately perceive a constant use of the strategy of detours and the strategy of passages as tools for his research. His first books start from urgent concerns in those turbulent and hopeful years of the end of the first half of the 20th century: The Great Moments of Indigenism in Mexico (Los grandes momentos del indigenismo en México) ${ }^{10}$ and The Ideological Process of the Revolution of Independence (El proceso ideológico de la revoluación de Independencia). ${ }^{11}$ "Two problems much in the grips of "cultural particularism' and not too promising to begin a philosophical career!", it may be repeated again, not without arrogance. However, it is noticeworthy that the general theories of ideology and of revolutionary processes never left Villoro; but perhaps more important was the concern for the indigenous peoples of Mexico, as well as for the "impure" plurality of cultures. ${ }^{12}$ These were problems that haunted him throughout his life. Despite these deep concerns, however, Villoro never confused philosophy with the sentimental pamphlet or, what is worse, with those easy and strident divagations that in the mass media of Latin America often try to pass as philosophy. In this regard, it is worth not forgetting some of his uses of the strategy of detours. In Villoro 2009, Villoro seeks to recover the "process of reason that goes from unfounded judgment to evident judgment", ${ }^{13}$ the epistemic process by which we abandon beliefs without support - among which ideological beliefs occupy a central place - to acquire those that possess it. In Villoro 2014 the author opposes ideological beliefs, whose function is to implant in society the current understandings backed by the incumbent power, to critical beliefs or, as he also calls them, "disruptive" beliefs. These and other uses of the detour strategy find a first culmination in his great book Belief, Personal and Propositional Knowledge, an original and meticulous epistemology, at least apparently in the most rigorous analytical tradition. I pointed out: "at least apparently" since as early as in the prologue Villoro asks unusual questions for the epistemology of this tradition (at least during the time he was writing the book). For example, he asks things like: "How does human reason work, through history, to reiterate situations of domination or, on the contrary, to free us from our restraints?",14

These and other uses of the strategy of detours led him to his books with a more directly moral and political content: Power and Value. Foundations for a Political Ethics (El Poder y el valor. Fundamentos de una ética política), ${ }^{15}$ Plural State, Plurality of Cultures (Estado plural, pluralidad de culturas), ${ }^{16}$ Challenges of Society to Come. Essays on Justice, Democracy and Multiculturalism (Los retos de la

\footnotetext{
${ }^{10}$ Villoro 1950.

${ }^{11}$ Villoro 1953.

12 The concern for the "purity" of a culture, a tradition, an identity, a blood, perhaps even for an academic discipline, is anything but pure. Sooner or later it is often revealed as a sinister concern: a tool to pursue and annihilate the other.

${ }^{13}$ Villoro 2009, 13.

${ }^{14}$ Villoro 1998a, 9.

${ }^{15}$ Villoro 1997.

${ }^{16}$ Villoro 1998b.
} 
sociedad por venir. Ensayos sobre justicia, democracia y multiculturalismo $)^{17}$ and his posthumous book The Alternative: Perspectives and Possibilities for Change (La alternativa: perspectivas y posibilidades de cambio). ${ }^{18}$ In these last works, Villoro returns to the strategy of passages and his concern to analyze concrete problems. He had used this strategy abundantly in his first two books and never stopped using it in his relentless journalistic work. ${ }^{19}$ (In his journal articles Villoro usually illuminates a problem, for example, social inequalities in Mexico, with abstract and general reflections; at the same time, he tries to exemplify those abstract and general reflections with details from the particular situations he discusses.) Along with the different political situations in Latin America that Villoro never stopped paying attention to and often suffered, Villoro was especially impacted by the 1994 Zapatista Army of National Liberation uprising. I cannot forget the scandal that sometimes was caused by seeing the image of an old Villoro - one of the patriarchs of Mexican culture - in Zapatista videos, sitting next to Subcomandante Marcos and other members of the National Liberation Army discussing liberalism and communitarianism, without refusing to question even prestigious arguments and theories, for example, of Jürgen Habermas and John Rawls. ${ }^{20}$ Against those thinkers Villoro insisted: it is urgent to attend to concrete injustices before, or at least together with, a positive and abstract theory of justice. According to Villoro, it is not possible to think about justice without building, at the same time, a theory of particular injustices: of the diverse experiences of exclusion and violence (exclusion and violence for being an indigenous person, for being a woman, for being poor, for being a refugee, for being a disabled person....). ${ }^{21}$ Only after using the strategy of passages,

\footnotetext{
${ }^{17}$ Villoro 2007.

${ }^{18}$ Villoro 2015. In this book, Villoro discusses the Zapatista's proposals and includes correspondence between him and Subcomandante Marcos.

19 Cfr. Hurtado 2017, 267-286. I slightly disagree with Hurtado: we do not find in Villoro a "conversion", but a radicalization of old positions. On the other hand, it is again worth remembering the Mexican liberals of the 19th century and not only their constant journalistic writing, but also their launching newspapers and magazines. Since then, this activity has been a frequent tradition among philosophers and, in general, among intellectuals in Latin America, at least until the beginning of the 21 st century. The concern that guided and still guides them was and is clear: to reinvigorate and influence with their interventions the public sphere.

${ }^{20}$ Radio Zapatista, http://radiozapatista.org./.

${ }^{21}$ In this regard, it would be of the utmost importance to discuss step by step the meticulous and acute paper Pappas 2017. In what follows I only sketch a few preliminary notes. Pappas observes: "The Latin American approach shared by decolonialists and Villoro can be contrasted with an atomistic approach to the problem of injustice. The atomistic approach is one that stresses the particularity of an injustice by neglecting history, and in general the relation of that event with other or with structural causes" (Pappas 2017, 5). Expressed in a different way, this quotaton may be read as suggesting that the atomistic approach ignores a nomadic epistemology and its strategies of passages and detours. As to the strategy of passages, Pappas emphasizes the need to start from the passages that articulate the most concrete experiences. In this sense, Pappas cites Villoro's second letter to Subcomandante Marcos: "Our starting point should be our particular experiences of marginalization and injustices" (Villoro 2015, 105). To this point of departure, Pappas opposes that of decolonialists and their tendency to take as their starting points general theories of the world-system and dependency. Thus, Pappas observes: "the quest for a comprehensive explanation and a grand historical narrative is also in
} 
of the passages from the abstract to the concrete, it becomes possible to carry out a detailed account of the constant and almost universal faults of the recognition of the other. $^{22}$ But, what can we do so we don't lose sight of such strategies?

In one of our last conversations, worrying about the dangers of converting the exchange of arguments - so characteristic of philosophy - into a parlor game or some kind of "vice" - a sort of "rationalizing" which sometimes becomes an endless rumination going nowhere, Villoro said: "Sometimes you have to think and reason, but other times you have to look and listen." ${ }^{23}$ I cannot think of a briefer way to summarize a principle of what I understand by nomadic epistemology and, in general, of nomadic thought: going from thinking and reasoning to looking and listening and vice versa, over and over again.

However, it is now time to pay attention to the sense in which nomadic thought is a "resource" for.

2.

Perhaps a small exercise in ordinary language philosophy with the English word "resource" and the Spanish word "recurso"-its usual translation-may help us to

danger of not capturing the historical and concrete particularity (pluralism, complexity, uniqueness) of actual injustices. When we start at the broad level of globality and history as decolonialists often do, there is a risk of oversimplifying and encouraging blindness about concrete injustices" (Pappas 2017, 8). To be sure, Pappas is right: to remain only in such a comprehensive point of view makes us blind to the particulars. Those extremely general "philosophies of history"-we have to call them some waythat seem to explain everything, not only do not genuinely explain anything but, what matters most, are little or not useful at all for concrete action: for the public policies they intend to guide. However, with his reasoning, does not Pappas seem to succumb to a version of the first false opposition we discussed, the one between abstract universalism and cultural particularisms? Perhaps many decolonialists could attack Pappas, on the one hand, by observing that introducing into the discussion that arrogant form of reason that is colonialist reason has a certain explanatory power. On the other hand, surely it will be indicated that concentrating too much on the particular experiences makes us return to the atomistic approach that Pappas himself began by criticizing. The solution is not, therefore, a static epistemology, and a dilemma between attention to specific experiences and circumstances and general or even universal theories, but to use from the standpoint of a nomadic epistemology the strategy of passages to go from one to the other and vice versa: to dissolve that false opposition, and to study the reciprocal determinations between the particular and the general in an endless sway.

${ }^{22}$ Cf., Villoro 2007, 15.

${ }^{23}$ On Villoro's emphasis on listening, I remember words from Ángeles Eraña: "from my perspective, the most important inheritance that [Villoro] leaves us has to do with his role as a student of the Zapatista school. A teacher who is a student. [But] to be a student you have to know how to listen (or learn to do it), and humility is required for this. We need to recognize that there are other ways, that light can come from other sides, that we know little, that we understand less." (See Eraña 2017, 287288). In this way, we can conclude that Villoro's nomadic epistemology is a consequence of his vital, personal nomadism: the events of history teach this great master to resist and to lose old desires and beliefs in order to start over again as an attentive apprentice who knows how to listen. In a beautiful memory of his father, writer Juan Villoro tells us something similar: "the scholar of Sahagun, Las Casas, Clavijero and Vasco de Quiroga became interlocutor of the indigenous communities, not with the desire to advise or illustrate, but to learn from them" (Villoro 2017, 334). 
immediately dissolve the second false opposition — or what might be considered, rather than a false opposition, just a difference of emphasis.

In English, a common use of the word "resource" refers to

1. Means for something, and/or

2. An ability to deal with a situation effectively.

The second sense can be understood as a precision of the first: the ability to know how to use those means effectively. A third common use refers to

3. An available supply, an available capital.

In this sense, "resourceful" refers to a rich country, or a rich tradition, or a rich person, because it is a country, a tradition, or a person with many resources or tools to acquire resources.

Regarding the Spanish word "recurso" we also find the uses already noted in relation to the English word "resource", but there's something more. The word "recurso" is also used as

\section{A claim against something.}

This last sense can be found in judicial practice: a "recurso de apelación" refers to an appeal procedure.

However, why should we focus on words like "resources", "recursos"? For example, Manuel Vargas has proposed to think of the value of philosophy in general and, therefore, of Latin American philosophy and, thus, also of Mexican philosophy, as a "cultural resource". ${ }^{24}$ I'd like to concentrate for a moment on these ideas, and then I will try to reconstruct the observations of Robert Elí Sánchez, Jr., ${ }^{25}$ not so much as objections to Vargas's argument, but as a nomadic remark: as developments and complements.

Vargas starts from the truth of the following statements:

- There are cultural differences.

- Cultural differences can have consequences. ${ }^{26}$

Among those consequences, there is the fact that each culture has different resources (sense 3). Vargas characterizes a cultural resource as:

any entity, practice, pattern of judgment, or collection whose nature and origin depends at least in part of the shared norms of a community of intentional agents. ${ }^{27}$

\footnotetext{
${ }^{24}$ Vargas 2010, 33-52.

${ }^{25}$ Sánchez 2014.

${ }^{26}$ Vargas 2010, 34.

${ }^{27}$ Vargas 2010, 37.
} 
He adds that these cultural resources are means to achieve certain ends effectively (senses 1 and 2 of "resources"); namely:

[cultural resources] tend to have cultural utility. Cultural utility is anything that assists in the flourishing, survival or perpetuation of a given culture, understood in a very broad way. ${ }^{28}$

As examples of practices bearing this cultural utility, Vargas points out the humanities and, among them, philosophy:

The humanities, those oft-unappreciated disciplines in the university system, are deeply involved in the production and preservation of complex cultural resources. The discipline of philosophy is a species of this more general project of producing and preserving complex cultural resources. Philosophy shares with other disciplines the general task of discovering, constructing, and preserving complex ideas with a wide degree of cultural utility. $^{29}$

As already suggested by the title of his paper- "On the Value of Philosophy: The Latin American Case", good Latin American philosophy does have value, as any good philosophy. Let me add: adopting an epistemic nomadism and its strategies of detours and passages is a good way to do good philosophy anywhere, a good way of discovering and building complex ideas beyond the usual problems and arguments. Both strategies are also a good means for the preservation of those ideas.

Suppose - an assumption that Vargas does not have to hold-that "resources of cultural utility" are exclusively understood as what we can call "affirmative values" or resources that are added to the established theories: resources added to the arguments or existing methodologies, but without criticizing or questioning them. Thus, "resources of cultural utility" would be reduced to introduce additions in a repertoire that is part, for example, of a static epistemology, in which there is no epistemic nomadism. We know in advance what types of questions to ask and the types of answers required, so it is forbidden to formulate other types of questions and answers. Consequently, not only the fourth use of the Spanish word "recurso" ("a claim against something") would be forgotten but, even more importantly, a task that has been and is constitutive of philosophy is being suppressed, namely, critical thinking, both singular and focal (related to a specific topic), and general (as a challenge to a whole way of understanding philosophy, society and life).

Precisely these omissions and suppressions-these suicidal omissions and suppressions for any genuine philosophy - are what Robert Elí Sánchez, Jr., fears are performed when the value of philosophy is introduced with the notion of "cultural resources". Thus, Sánchez points out that this is a way in which the emphatically critical, negative value that philosophy must have is neglected:

\footnotetext{
${ }^{28}$ Vargas 2010, 38.

${ }^{29}$ Vargas 2010, 41.
} 
the value of radically destroying pretenses, traditions, and cultural norms and of injecting a sense of uncanniness, not-knowing, and solitude into our lives. ${ }^{30}$

In this regard, Sánchez insists on understanding philosophy also as a nomadic thought that, from time to time, becomes extreme and branched, and is formulated as a general challenge, "philosophy as a disruption of an entire culture":.31

What is potentially valuable is not only what distinguishes it (Latin American philosophy), but a challenge to the kind of question we ask about it or the kind of answer that satisfies us. ${ }^{32}$

In this way, Sánchez takes into account and underlines the importance of the strategy of detours in philosophical work: "this awareness raises [...] particular questions inside philosophy about the value of diversity". ${ }^{33}$ But not only that. With this awareness, Sánchez does not neglect the strategy of passages in as much as he introduces "critically important questions about whether the nature of philosophy is determined in part by who participates, and how we should respond if it is.",34 It is not by chance, then, that from these ideas, Sánchez partially reaches conclusions against Vargas by pointing out that:

Philosophy does produce, preserve, and propagate complex cultural resources certainly. But it can also disrupt and destabilize our grip on the manifestation of a tradition or way of life. ${ }^{35}$

In this passage, the two decisive words are "disrupt" and "destabilize". In this sense, Sánchez is right not neglecting the negative, critical, therapeutic value of philosophy or, in general, of culture; but he has little reason to consider that this value cannot also be subsumed under the expression "cultural resources" or, more explicitly, under "resources of cultural utility". We must not forget the comprehensive and extremely friendly sense with which Vargas introduces the concept of cultural utility: "anything that assists in the flourishing, survival or perpetuation of a given culture, understood in very broad ways". Due to their defiant attitude and therapeutic tendencies, other frequently anomalous philosophers, like Socrates, Kierkegaard or Wittgenstein - or Villoro in Mexico or, in the rest of Latin America, José Martí or Carlos Vaz Ferreira, offered essential resources for the "flourishing, survival or perpetuation", not only of philosophical culture, but of their societies. Hence, the singular and general criticisms, as well as the challenges and therapies, are also essential "cultural resources".

\footnotetext{
${ }^{30}$ Sánchez 2014, 5.

${ }^{31}$ Sánchez 2014, 4.

${ }^{32}$ Sánchez 2014, 6.

${ }^{33}$ Sánchez 2014, 7.

${ }^{34}$ Sánchez 2014, 7.

${ }^{35}$ Sánchez 2014, 7.
} 
If, next to the first false opposition - the particular versus the universal - and to the second quasi-false opposition - the positive versus the negative values of cultural resources-I propose that there is a genuine opposition, we might ask now, rather impatiently, what kind of philosophy can be opposed to thinking it as "cultural resources" of a nomadic epistemology that includes valuable fragments of Latin American philosophy and, therefore, also of Mexican philosophy?

\section{3.}

I have explicitly alluded at least twice in this paper to an arrogant attitude. (But of course one can suspect that arrogance also lurks, latently, or manifestly, on other occasions). For example, from a static epistemology Mexican philosophy has been arrogantly cornered to make a choice in the false opposition between abstract universalism and culturalist particularism. Arrogance was also assumed by those who consider it unpromising to begin a philosophical career using the strategy of passages in studies as particular as the indigenism in Mexico and the ideology of Mexican independence wars. ${ }^{36}$ However, both attitudes are, if I am not mistaken, only indications of a relatively common way of wrongly engaging philosophy and, more comprehensively, culture and life. For that reason, I denounce what I call an "arrogant reason" as a basic way of orienting ourselves or, more precisely, of disorienting ourselves, not only in philosophy but also in problems in general. ${ }^{37}$ I'll take now a moment to examine what would be maxims on which this reason is put into practice.

For example, one or several agents might fall prey to arrogant reasoning when they refuse to investigate unusual problems with the strategy of detours-for example, the authority of a philosophical canon, or when one refuses to ponder arguments about racism and homophobia, or with the strategy of passages, going from the particular - from concrete situations and even individual oppression - to the general - a radical change of political regime - and vice versa. ${ }^{38}$ Instead of using these strategies, one only seeks to display an affiliation. These affiliations may be, for example, to a powerful social heritage, a strong economic group, or even to a style of

\footnotetext{
${ }^{36}$ Another example of the use of the strategy of passages are the following statements by Leopoldo Zea: "The point of departure of those who think is always the concrete man.... This is the golden rule of philosophy: to start from our own, concrete problems, and then to look for the universal that may be within in it.... I mean: in my identity I run into other similar identities, I find that there are other human beings who have problems like me: problems like those that all humans have at all times". See Pereda 2013, 98-99.

${ }^{37}$ In Villoro 2007 the author opposes arrogant reason to the reasonable: "Reasonable, in fact, are beliefs and norms that do not express an 'arrogant reason' (Carlos Pereda) but a reasonable exercise of justice; reasonable is also a political theory that leads to an effective democracy". Villoro 2007, 11.

${ }_{38}$ The writer Alfonso Reyes (1889-1959), had already warned, some time before the philosophers that Orosco includes as "culturalists"- several members of the Hyperion group - that "the only way to be profitably national is to be generously universal". See Reyes 1952. According to the strategy of passages, it is also worth considering, for example, with Zea, the inverse warning: the only way to be profitably universal is to be generously national, and, perhaps, even generously personal. (Cfr. Hurtado 2015.) On the importance of this group, see also Stehn 2018.
} 
thought that prevails at the moment. Of course, reducing one's identity to a "prestigious affiliation" not only demarcates it-it also makes us forget our deficiencies and protects us through delusions. This first maxim of arrogant reason commands, then: In front of any problem or conflict, exhibit your prestigious affiliation.

In turn, this affiliation receives, as part of its support and, sometimes, as its only support, the emphatic disdain or contempt and, at times, the militant rejection that those agents or that social group directs against those who oppose or are indifferent to it. For example, anyone who proposes a course in Mexican philosophy explicitly or implicitly will be prescribed the already stated phrase "don't bother". This second maxim of arrogant reason commands: To justify yourself, in addition to exhibiting an affiliation, show and, if possible, express your disdain or contempt towards everything that is not subsumed under that affiliation.

On the other hand, arrogant uses of reason tend to immunize our presuppositions. The agent or agents firmly reject in advance any critical, focal or general questions, especially when the latter questions become comprehensive challenges that perhaps put into question the affiliation that is boasted. Thus, a third maxim of arrogant reason commands: In front of difficulties with your affiliate identity, shield yourself.

I said that, along with the two false oppositions, there was a genuine opposition I wanted to introduce. The opposition that I want to defend is this: against the operation of arrogant reason, I want to introduce another principle of nomadic thought: act with a porous reason. For example, time and again the agent or agents come and go between numerous affiliations and points of view. These affiliations imply links and perspectives relating not only to the past and the present, but also to the practices to be carried out in the future. With considerations like these, I formulate a first maxim of porous reason: When facing doubts, ambiguities, conflicts, act assuming numerous affiliations and points of view.

However, we must not forget that common vice,_- "rationalizing"-and its disintegrating extreme - endless rumination. This addiction, coupled with the fear often caused by the risks involved in looking and listening to what we are not used to, and in supporting and understanding other desires, other beliefs, and other life proposals, often causes us to react by humiliating others. Therefore, I would like to formulate as follows a second maxim of porous reason: Act from real or imaginary conversations in which you interact not only as someone who thinks and reasons, but also as someone who looks and listens, without neglecting the possibility of introducing scientific arguments in such conversations.

Let us suppose now that, based on these maxims, we get to strengthen habits that sometimes imply questioning our most cherished schemes for appreciation with the purpose of detoxifying ourselves from our own affiliations. This leads us to a third maxim of porous reason: Let yourself be challenged.

I conclude then taking up the question "Why courses on Mexican philosophy?" Or, more comprehensively: "Why courses on Latin American philosophy?" The halfway response I have proposed implies expanding the tradition, enriching it. However, why should these other sometimes idiosyncratic and unique voices be of 
interest? Philosophy has always been, and is, on the brink of suicide when it does not consider the changing plurality of voices, not only in continuity, but also in opposition. We rarely know in advance where these criticisms, these challenges will come from. This is another way to say: philosophy or, at least, good philosophy, has never feared of working from nomadic thought and, therefore, with porous reason.

Of course, each one of these statements can be questioned, and can be subjected to new criticisms and challenges. However, taking these questions and challenges into account would lead us to longer, perhaps much longer, elaborations than those we can provide here.

\section{REFERENCES}

Eraña, Ángeles (2017), "Luis Villoro. La filosofía como acto politico", in Pedro Stepanenko (ed.), Luis Villoro: Conocimiento y emancipación. Homenaje póstumo del Instituto de Investigaciones Filosóficas (Mexico: UNAM), 287-302.

Gracia, Jorge (2010), "Identity and Latin American Philosophy", in Susana Nuccetelly, Ofelia Schutte and Octávio Bueno (eds.) (2010), 253-268.

Hurtado, Guillermo (ed.) (2015), El Hiperión, introduction by Guillermo Hurtado (Mexico: UNAM).

- (2017), "Luis Villoro en la La Jornada: crónica de una conversión", in Pedro Stepanenko (ed.), Luis Villoro: Conocimiento y emancipación. Homenaje póstumo del Instituto de Investigaciones Filosóficas (Mexico: UNAM), 267-285.

Jaksic, Iván (ed.) (2015), Debating Race, Ethnicity, and Latino Identity: Jorge Gracia and His Critics (Columbia University Press).

Maciel, David (1984), "Ignacio Ramírez, Ideologist of Social Liberalism in Mexico", prologue to Vol. I of Ramírez (1984-1989).

Máriategui, José Carlos (1996), "Is There Such a Thing as Hispanic-American Thought?”, in Michael Pearlman (ed. and trans.) (1996), The Heroic and Creative Meaning of Socialism (New Jersey: Humanities Press), 116-118.

Medina, José (2012), The Epistemology of Resistance. Gender and Racial Oppression, Epistemic Injustice and Resistant Imaginations (Oxford: Oxford University Press).

Monsiváis, Carlos (1985), “The Radical Expression of Ignacio Ramírez”, Prologue to Vol. III of Ramírez (1984-1989).

Nuccetelly, Susana, Ofelia Schutte and Octávio Bueno (eds.) (2010), A Companion to Latin American Philosophy (Malden, MA: Wiley-Blackwell).

Orosco, José-Antonio (2016), "The Philosophical Gift of Brown Folks: Mexican American Philosophy in the United States", APA Newsletter - Hispanic / Latino Issues in Philosophy 15.2: 23-24.

Pappas, Gregory F. (2017), "The Limitations and Dangers of Decolonial Philosophies: Lessons from Zapatista Luis Villoro", Radical Philosophy Review 20.2: 265-295.

Pereda, Carlos (1987), Debates (Mexico: Fondo de Cultura Económica).

- (2006), "Latin American Philosophy: Some Vices", Journal of Speculative Philosophy 20.3: 192-203.

- (2013), La filosofía en México en el siglo XX. Apuntes de un participante (Mexico: Conaculta). 
- (2017), "Luis Villoro: Un Ulises del recomenzar", in Pedro Stepanenko (ed.), Luis Villoro: Conocimiento y emancipación. Homenaje póstumo del Instituto de Investigaciones Filosóficas (Mexico: UNAM), 13-32.

- (2018), Lessons in Exile, trans. by Sean Manning (Brill, Rodopi).

Ramírez, Ignacio (1984-1989), Complete Works in 8 volumes, Jorge L. Tamayo Scientific Research Center.

Ramos, Samuel (1972), Profile of Man and Culture in Mexico, trans. by Peter B. Earle (Austin: University of Texas Press).

Reed-Sandoval, Amy (2016), “' Immigrant' or 'Exiled'? Reconceiving the Desplazada/os of Latin American and Latina/o Philosophy", APA Newsletter Hispanic / Latino Issues in Philosophy 15.2: 11-14.

Reyes, Alfonso (1952), "A vuelta de correo", in La x en la frente (Mexico: Porrúa and Obregón), 41-69.

Reyes Heroles, Jesús (1957), El liberalismo mexicano (Mexico: Fondo de Cultura Económica).

Rivera Berruz, Stephanie (2016), "Review of Jaksic, Iván (ed.) (2015), Debating Race, Ethnicity, and Latino Identity: Jorge Gracia and His Critics", APA Newsletter, Hispanic/Latino Issues in Philosophy 15.2: 28-30.

Salazar Bondy, Augusto (2004), "The Meaning and Problem of Hispanic American Philosophical Thought", in Jorge J.E. Gracia and Elizabeth Millán-Zaibert (eds.), Latin American Philosophy for the 21st Century (New York: Prometheus), 381-398.

Sánchez, Carlos Alberto (2012), The Suspension of Seriousness: On the Phenomenology of Jorge Portilla (Albany: State University of New York).

Sánchez, Jr., Robert Elí (2014), "Strengthening the Case for Latin American Philosophy: Beyond Cultural Resources", APA Newsletter Hispanic/Latino Issues in Philosophy 13.2: 2-9.

Stehn, Alexander (2018), "Latin American Philosophy", in the Internet Encyclopedia of Philosophy (http://www.iep.utm.edu/latin-am/).

Vargas, Manuel (2010), "On the Value of Philosophy: The Latin American Case", Comparative Philosophy 1.1: 33-52.

Villoro, Juan (2017), "Por ejemplo, un puñado de sal", in Pedro Stepanenko (ed.), Luis Villoro: Conocimiento y emancipación. Homenaje póstumo del Instituto de Investigaciones Filosóficas (Mexico: UNAM), 327-351.

Villoro, Luis (1950), Los grandes momentos del indigenismo en México (Mexico: el Colegio Nacional).

- (1953), El proceso ideológico de la revoluación de Independencia (Mexico: UNAM).

- (1997), El Poder y el valor. Fundamentos de una ética política (Mexico: Fondo de Cultura Económica).

- (2014), El concepto de ideología y otros ensayos (Mexico: Fondo de Cultura Económica).

- (1998a), Belief, Personal and Propositional Knowledge, trans. by David Sosa and Douglas McDermid (Brill, Rodopi Philosophical Studies, vol. 3).

- (1998b), Estado plural, pluralidad de culturas (Mexico: Paidós/Facultad de Filosofía y Letras-UNAM).

- (2007), Los retos de la sociedad por venir. Ensayos sobre justicia, democracia y multiculturalismo (Mexico: Fondo de Cultura Económica).

- (2009), La Idea y el Ente en la filosofía de Descartes, 2nd ed. (Mexico: Instituto de Investigaciones Filosóficas-UNAM). 
- (2015), La alternativa: perspectivas y posibilidades de cambio (Mexico: Fondo de Cultura Económica).

Zea, Leopoldo (2004), "Identity: A Latin American Philosophical Problem", in Jorge J.E. Gracia and Elizabeth Millan-Zaibert (eds.), Latin America Philosophy for the 21st Century (New York: Prometheus), 369-378. 